\title{
AWARENESS REGARDING PATIENT RIGHTS AMONG HOSPITALIZED PATIENTS IN A HOSPITAL OF RUPANDEHI
}

\author{
Saraj Gurung, ${ }^{1}$ Ritika Sapkota ${ }^{2}$
}

ABSTRACT

\section{INTRODUCTION}

Patients' rights is recently introduced term in health sciences literature and practice and has become an important part of modern health care practice. Patients now are much more aware of what they expect from health care professionals, when they enter the health care environment. The aim of the study was to find out the knowledge regarding patient rights among hospitalized patients.

\section{MATERIAL AND METHODS}

Descriptive study was conducted to find out the knowledge regarding patients' rights among hospitalized patients. Seventy two respondents were selected by using convenience sampling technique. Semi-structured interview schedule was used to collect the data and collected data were analyzed by using descriptive statistics with Statistical Package for Social Science software (SPSS) version 20.

\section{RESULTS}

The findings of the study revealed that $59.72 \%$ of the respondents had high knowledge regarding patient rights. Cent percent of the respondents had knowledge that being treated with respect, equitable treatment, decide to participate in human experiment are patient rights. Ninety three percent, $92 \%$ and $31.90 \%$ respondents had knowledge that right to informed consent, right to confidentiality, right to privacy and right to leave against medical advice are patients' rights respectively.

\section{CONCLUSION}

Based on the findings of the study, it is concluded that nearly three fourth of the respondents have high knowledge regarding patients' rights. It is recommended that management of hospital should conduct orientation program regarding human rights to health care providers to deliver health care in human right aspect.

KEYWORDS Awareness, hospitalized patients, patient rights

1. Universal College of Nursing Sciences, UCMS, Siddarthnagar-1, Rupandehi, Nepal

2. Mankamana Hospital, Bharatpur-10, Chitwan, Nepal

DOI: https://doi.org/10.3126/jucms.v7i1.24693

For Correspondence

Ms. Saraj Gurung

Universal College of Nursing Sciences

Bhairahawa, Nepal

Email: g.saraj@gmail.com 


\section{INTRODUCTION}

The notion of patient rights has been developed on the basis of concept of the person, and the fundamental dignity and equality of all human beings recognized in the Universal Declaration of Human Rights in 1948. Since then numerous declarations and professional ethical codes have sought to ensure the protection of fundamental human rights and to promote the humanitarian treatment of all patients. The rights of a patient are a set of rules of conduct which govern the interaction between the patient and health care professionals. Every patient has a right to be informed about their rights and also the responsibility of the healthcare providers. ${ }^{2}$ The implementation of patient's rights, as an extension of human rights, is an important index for health service quality. Patients have the right to accessible, equal and constant health services, receive information, make decisions freely regarding the methods of treatment and their physicians, privacy, have their psychosocial and spiritual values respected. ${ }^{3}$

Patient rights are the specification of general human rights. The rights define the patient position in relation to health institutions or medical professions providing broadly understood health service. The protection system of patient rights outlined by international legal and ethical regulations is detailed to specific social, political and economic realities by internal legal systems of individual state. ${ }^{4}$ The study conducted to examine the patients' awareness about their rights in Tehran, Iran shows that $21 \%$ of the patients had poor, $72 \%$ had moderate, and $7 \%$ had good awareness of privacy and confidentiality are patients'right.

\section{MATERIAL AND METHODS}

Descriptive study was conducted to find out awareness regarding patients' rights in Universal College of Medical Sciences, Teaching Hospital, Siddharthanagar -1, Rupandehi, Province-5. Seventy two patients who were men or women age group between 20-60 years has been hospitalized for more than 3 days in different wards were selected as sample for the study by using non- probability convenience sampling. Twenty-nine questions were included in pre-tested semistructured interview schedule. By using interview schedule, the data was collected on month of August. Collected data was analyzed by using descriptive statistics; frequency, percentage, mean and standard deviation with Statistical Package for Social Science software (SPSS) version 20.

\section{RESULTS}

Regarding awareness on patient' right, $100 \%$ and $93.1 \%$ of respondents answered to be treated with respect, right to access health services on time, right to equitable health services and right to respect of socio-cultural practices are patients' right respectively (Table 1). Respondents awareness regarding patients' right to self decision, $100 \%, 95.90 \%$, $93.10 \%, 84.70 \%$ and $31.90 \%$ respondents answered that right to decide to participate in human experiment, right to complain about health services, right to informed consent, right to be discharged on personal request and right to leave against medical advice (Table 2).

Regarding treatment, $100 \%, 98.60 \%$ and $90.30 \%$ of respondents answered that right to know treatment plan, right to know the alternatives of treatment, right to have continuity of care and right to make decision of treatment are patients right. Regarding right to information $100 \%$ of respondents answered that right to know about investigation, right to know disease condition, and explanation of itemized bill are patients' right respectively. Whereas $98.60 \%$ and $94.40 \%$ respondents answered that right to know hospital rules and regulation, right to know diagnosis, right to be referred for a second opinion and right to be treated by a named health care provider are patients' right to information (Table 3). Cent percentage of respondents answered provision of third person of same sex during examination period, right to get treatment in safe environment and right to get legal treatment from court in case of any damages or loss are patients' right respectively. Besides that $93.1 \%$ and $91.7 \%$ answered that right to confidentiality and provision of separate place for examination are patients' right (Table 4). Regarding level of awareness regarding patients' right, $59.72 \%$ of the respondents had high and $40.27 \%$ had low awareness (Table $5)$.

Table 1. Respondents' awareness regarding patient's right to dignity and equality $n=72$

\begin{tabular}{lcc}
\hline Variables & \multicolumn{2}{c}{ Correct Responses } \\
& Frequency & Percentage \\
\hline Right to dignity & 72 & 100.0 \\
Right to be treated with respect & 67 & 93.1 \\
Right to respect of socio/cultural practices & & \\
Right to access to health care & 72 & 100.0 \\
Right to access health service on time & 72 & 100.0 \\
Right to equitable health services & & \\
\hline
\end{tabular}

Table 2. Respondents' awareness regarding patient's right to self decision $n=72$

\begin{tabular}{lcc}
\hline Right to Autonomy & \multicolumn{2}{c}{ Correct Responses } \\
& Frequency & Percentage \\
\hline Right to make decision about investigation & 61 & 84.7 \\
Right to informed consent & 67 & 93.1 \\
Right to be discharged on personal request & 67 & 93.1 \\
Right to leave against medical advice & 23 & 31.9 \\
Right to complain about health services & 69 & 95.8 \\
Right to decide to participate in human & & 100.0 \\
experiment & 72 &
\end{tabular}


Table 3. Respondents' awareness regarding patients' right to treatment and information $n=72$

\begin{tabular}{lcr}
\hline Variables & \multicolumn{2}{c}{ Correct Responses } \\
& Frequency & Percentage \\
\hline Right to treatment & & \\
\hline Right to know treatment plan & 72 & 100.0 \\
Right to make a treatment choice & 65 & 90.3 \\
Right to know alternatives of treatment & 71 & 98.6 \\
Right to have continuity of care & 71 & 98.6 \\
& & \\
Right to information & 71 & 98.6 \\
Right to know hospital rules and regulations & 71 & 98.6 \\
Right to know diagnosis & 72 & 100.0 \\
Right to know about investigation & 71 & 98.6 \\
Right to be referred for a second opinion & 72 & 100.0 \\
Right to know about disease condition & 68 & 94.4 \\
Right to be treated by a named health care provider & 72 & 100.0 \\
Right to explanation of itemized bill & \\
\hline
\end{tabular}

Table 4. Respondents' awareness regarding patient's right to privacy, safety and legal rights $n=72$

\begin{tabular}{lcr}
\hline Variables & \multicolumn{2}{c}{ Correct Responses } \\
& Frequency & Percentage \\
\hline $\begin{array}{l}\text { Right to provision of separate place for } \\
\text { examination }\end{array}$ & 66 & 91.70 \\
$\begin{array}{l}\text { Right to provision of third person of same } \\
\text { sex during examination }\end{array}$ & 72 & 100.0 \\
$\begin{array}{l}\text { Information concerning one's health should not } \\
\text { disclose }\end{array}$ & 67 & 93.10 \\
$\begin{array}{l}\text { Right to get treatment in safe environment } \\
\text { Right to get legal treatment from court in case } \\
\text { of any damages or loss }\end{array}$ & 72 & 100.00 \\
\end{tabular}

Mean percentage score of right to privacy $=68.33$

Table 5. Respondents' level of awareness regarding patients' rights

\begin{tabular}{lcr}
\hline Level of awareness & Frequency & Percentage \\
\hline High & 43 & 59.72 \\
Low & 29 & 40.27 \\
Total & 72 & 100.0 \\
\hline
\end{tabular}

Mean score $=27.65 ;$ Total score $=29$

\section{DISCUSSION}

The study was conducted to find out the awareness regarding patients' rights among hospitalized patients in a hospital of Rupandehi. Regarding socio-demographic variables, mean age of the respondents was 34.94 years standard deviation 11.708. Sixty-eight percentage were male, $34.70 \%$ were Pahadi Janjati , $68 \%$ were literate and $25 \%$ were service holder. Mean day of hospitalization was 9.88 and standard deviation 11.776 .

Cent percent of the respondents knew that right to be treated with respect, right to decide to participate in human experiment and right to know treatment plan are patients' right respectively. Findings of the study are not consistent with study ${ }^{6}$ conducted in Riyadh, Saudi Arabia which shows $94.80 \%, 77.80 \%$ and $89.60 \%$ of respondents were aware about right to respectful care, right to decide to take part in any purposed research and right to know treatment are patients' right respectively. Cent percent of the respondents knew that right to access health service on time, right to get legal treatment from court in case of any damages or loss right and to get treatment in safe environment are patients' right. Findings are not consistent with study ${ }^{7}$ of Mangalore, India which shows $58 \%$ and $55 \%$ respondents were aware about right to access health service on time and right to file a civil court to get grievance redressal and study ${ }^{8}$ conducted in WadiMedani Teaching Hospital, Sudan, which shows that $87 \%$ were aware of right to get treatment in safe environment are patients' right.

About $99 \%, 96 \%$ and $95.8 \%$ respondents knew that right to know the alternatives of treatment, right to have continuity of care and right to complain about health services are patients' right. Our findings were not consistent with the study ${ }^{9}$ Riyadh, Saudi Arabia shows $51.20 \%$ of respondents were aware of right to know the alternatives of treatment. Study ${ }^{10}$ conducted in Poland shows that $80.80 \%$ were aware of right to continue treatment and study ${ }^{11}$ conducted in Middle East Ezypt, Sudan, Lebanon and Saudi Arabia shows that $75 \%$ were aware of right to complain about health services are patientts' right.

Ninety-three percentage and $90 \%$ of the respondents knew that right to confidentiality and right to make decision of treatment are patients' right. Findings are not consistent with study $^{7}$ of Mangalore, India shows that $85 \%$ respondents were aware of right to confidentiality and study ${ }^{6}$ conducted in Riyadh, Saudi Arabia which shows 58\% answered right to make decision of treatment are patients' right

Ninety-four percentage and $93 \%$ of respondents knew that right to be treated by named health care provider and right to informed consent are patients' right. Findings are consistent with study ${ }^{10}$ conducted in Poland shows that $97.30 \%$ of respondents were aware that right to know the name of health care provider and study ${ }^{12}$ conducted in Kano, Nigeria which shows that $97.50 \%$ respondents were aware of right to informed consent are patients' right.

\section{CONCLUSION}

On the basis of findings of the study it is concluded that nearly two third of patients have overall high level knowledge regarding patients rights. Cent percentage of the patients have right to be treated with respect, right to decide to participate in human experiment and right to know treatment plan, right to access health service on time, right to get legal treatment from 
court in case of any damages or loss right and to get treatment in safe environment are patients' right.

Nearly cent percentages of patients have knowledge that right to know the alternatives of treatment and right to have continuity of care. More than four fifth of patients are aware that right to complain about health services, right to confidentiality, to be treated by named health care provider and right to informed consent are patients' right. Just above four fifth and nearly one third of patients are aware of right to make decision about investigation and right to leave against medical advice are patients' right.

\section{ACKNOWLEDGEMENTS}

Researchers deeply express their heartfelt thanks to all who participated in the study for immense support and cooperation. Researchers express their deep and sincere gratitude to all those experts for their valuable judgment, constructive feedbacks and enlightening suggestions throughout the study.

\section{REFERENCES}

1. Välimäki M, Kuosmanen L, Kärkkäinen J, Kjervik DK. Patients' rights to complain in Finnish psychiatric care: An overview. International journal of law and psychiatry. 2009 May 1;32(3):184-8.

2. Agrawal U, D'Souza BC, Seetharam AM. Awareness of Patients' Rights among Inpatients of a Tertiary Care Teaching HospitalA Cross-sectional Study. Journal of clinical and diagnostic research: JCDR. 2017 Sep;11(9):IC01.

3. Heidari A, Ahmadpour Z, GharehBoughlou Z. Patients and nurses awareness of patient's rights: A comparative study. Health, Spirituality and Medical Ethics. 2013;1(1).

4. Rabiega-Przylecka A. Patient's rights in Poland against the background of new regulations. Med. \& L. 2012;31:43.

5. Mohammadi M, Larijani B, Razavi SH, Fotouhi A, Ghaderi A, Madani SJ, Shafiee MN. Do patients know that physicians should be confidential? study on patients' awareness of privacy and confidentiality. Journal of medical ethics and history of medicine. 2018;11: (1)

6. Aljerian, K., Asiri, F., Al-Zeer, M., Al-Mutairi, S., Al-Mutairi, R., \& Alhomair, N. Assessment of hospitalized patients' differential awareness of their rights. International Academic Research Journal of Medical Sciences, 2015, 1:(1), 12-22

7. Fernandes AB, D'Cunha S, Suresh S. Patient rights, awareness and practice in a tertiary care Indian Hospital. International Journal of research foundation of hospitals \& Health Care Administration. 2014;2(1):25-30.
8. Younis AA, Hassan AH, Dmyatti EM, Elmubarak MA, Alterife RA, Salim RE, Mohamed SA, Ahmed WS. Awareness and practice of patients' rights among hospitalized patients at WadMedani Teaching Hospital, Sudan. EMHJ-Eastern Mediterranean Health Journal. 2017;23(2):80-6.

9. FaridaM. Habib and Hind Sulaiman Al-Siber, Assessment of Awareness and Source of Information of Patients' Rights: a Cross- sectional Survey in Riyadh Saudi Arabia. merican Journal of Research Communication. 2013;1(2):1-9.

10. Krzych $Ł J$, Ratajczyk D. Awareness of the patients' rights by subjects on admission to a tertiary universityhospital in Poland. Journal of Forensic and Legal Medicine. 2013 Oct 1;20(7):9025.

11. Hifnawy T, Kobrosly S, Edwards H, Anwar M, Zahran D, Silverman H. Patients' attitudes and perceptions regarding research and their rights: a pilot survey study from the Middle East. Eastern Mediterranean health journal= La revue de sante de la Mediterranee orientale= al-Majallah al-sihhiyah li-sharq al-mutawassit. 2017 Aug 27;23(7):461.

12. Sulaiman AI, Ayyuba R, Diggol IG, Haruna IU. Knowledge, attitude and perception of patients towards informed consent in obstetric surgical procedures at Aminu Kano Teaching Hospital. Nigerian Journal of Basic and Clinical Sciences. 2015 Jan $1 ; 12(1): 45$. 